\title{
Penggunaan Media ICT dalam Implementasi Problem Based Learning Pada Pelajaran IPA Materi Siklus Hidup
}

\author{
${ }^{1}$ Endrayana Putut Laksminto Emanuel, ${ }^{2}$ Ani Muzarotul Zakiyah \\ ${ }^{1,2}$ Fakultas Bahasa dan Sains, Universitas Wijaya Kusuma Surabaya, \\ Jl. Dukuh Kupang XXV/54 Surabaya, Jawa Timur, Indonesia \\ Email: 1endrayanaputut29@gmail.com, ${ }^{2}$ animuza40@gmail.com
}

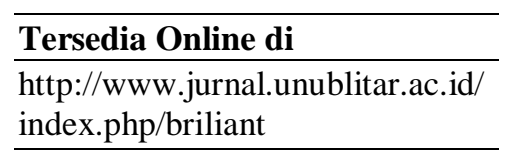

\section{Sejarah Artikel}

Diterima pada Desember 2021

Disetuji pada Mei 2021

Dipublikasikan pada Mei 2021

Hal. 321-328

\begin{tabular}{l}
\hline Kata Kunci: \\
\hline $\begin{array}{l}\text { Media ICT; model } \\
\text { pemahaman konsep }\end{array}$
\end{tabular}

\section{DOI:}

http://dx.doi.org/10.28926/briliant .v3i4.650

\begin{abstract}
Abstrak: Kurangnya kreatifitas guru dan keaktifan siswa di dalam kegiatan pembelajaran masih menjadi permasalahan yang penting untuk diteliti. Penelitian bertujuan untuk mengetahui bahwa media ICT dalam model $P B L$ bisa meningkatkan kemampuan siswa memahami konsep IPA. Metode penelitian yang digunakan adalah quasi experiment kuantitatif. Instrumen yang digunakan ialah pengumpulan data lembar tes dan dokumentasi . Tes hasil belajar siswa yang diharapkan bisa meningkatkan pemahaman konsep peserta didik terhadap belajarnya. Hasil penelitian menunjukkan bahwa penggunaan media ICT mampu meningkatkan pemahaman konsep siswa pada materi siklus hidup hewan.
\end{abstract}

\section{PENDAHULUAN}

Manusia merupakan makhluk hidup yang dapat menjalankan kehidupannya dengan melihat suatu pendidikan. Pendidikan yaitu suatu usaha sadar dan terstruktur untuk bisa menciptakan perubahan belajar mengajar menjadi aktif yang dapat membuat kemampuan dari dalam diri untuk mempunyai kendali diri tingkah laku, keterampilan dan berakhlak mulia yang di perlukannya di dalam suatu masyarakat (Sudarsana et al., 2019). Kegiatan pendidikan yang diberikan pemerintah untuk sekolah dasar yaitu bertujuan untuk memberikan pesan kepada siswa agar nanti bisa hidup dalam bermasyarakat dan peserta didik juga dapat meneruskan pendidikanya ke tingkat yang lebih tinggi lagi.

Di dalam pendidikan mata pelajaran IPA (Ilmu Pengethuan Alam) sangat penting di ajarkan karena karena IPA banyak mempelajari berbagai konsep sains yang ada keterkaitanya dengan alam semesta, baik benda yang ada di bumi maupun benda yang ada di langit bahkan sampai luar angkasa sekalipun yang tidak dapat diamati oleh indera secara langsung itu bisa kita pelajari dalam mata pelajaran IPA, maka dari itu peserta didik perlu adanya pemahaman konsep yang baik mengenai ilmu tersebut. IPA juga merupakan mata pelajaran yang bisa dikatakan dapat membantu siswa menguasai, memahami sejumlah fakta dan gambaran yang ada dibumi yang dapat di terapkan di kehidupan nyata. Pemahaman adalah salah satu belajar yang bisa dikatakan lebih tinggi dibanding 
pengetahuan karena dengan kegiatan ini siswa dapat berpikir secara kritis tentang apa yang sudah di pelajarinya dengan melakukan percobaan secara langsung (Hartini, 2019; Sudarsana,dkk., 2019). Dari hasil pengamatan di sekolah, kebanyakan guru yang hanya menyampaikan materi dengan cara ceramah dan keaktifan siswa sangatlah kurang, dikarenakan model pembelajaran yang kurang menarik.

Ilmu alam yang mengajarkan peristiwa di alam bumi ini bisa disebut dengan mata pelajaran Ilmu Pengetahuan Alam karena sifatnya sangat keterkaitan dengan alam sehingga IPA bisa diartikan sebagai kumpulan gagasan pengetahuan yang fakta, dan prinsip saja namun IPA juga bisa dikatakan suatu proses baru oleh ilmuan atau mencari tahu. Trianto mengemukakan jika IPA adalah suatu gabungan tori yang sudah tersusun secra terencana yang penerapanya melalui pengamatan dan eksperimen percobaan yang dapat menumbuhkant perasaan ingin tahu yang tinggi (Salim Nahdi, Yonanda, \& Agustin, 2018; Surahman, Paudi, \& Tureni, 2015)

Deliany, Hidayat, \& Nurhayati(2019) mengemukakan bahwa kemampuan seorang untuk bisa memahami suatu gagasan tertentu dan seseorang dikatakan bisa memahami suatu gagasan itu artinya siswa bisa menangkap makna atau arti dari suatu konsep tersebut. Dari pendapat tersebut bisa disimpulkan bahwa siswa yang bisa menjelaskan ulang materi yang sudah ia pelajari berdasarkan pemahaman dan kata-katanya sendiri itu termasuk siswa yang sudah mempunyai pemahaman, sehingga pembelajaran tersebut bisa di katakan dengan bermakna. Menurut (L.E., 2018), ada tujuh indikator untuk pemahaman konsep yaitu menginterpretasikan, memberikan contoh, mengklasifikasikan, meringkas, menduga, membandingkan, menjelaskan. Interpretasi merupakan penafsiran dari contoh nyata menjadi gagasan tertentu tanpa mengubah makna dengan menggunakan kata-kata. Pemberian contoh dan pengkategorian kemudian menentukan tema yang ditunjukkan dengan mengabstraksikan. Meringkas dan menduga apa yang akan terjadi dari suatu gagasan, dan menjelaskan dengan konstruksi model sebab akibat dari gagasan tersebut.

Ada beberapa problem yang bisa ditemukan dalam pembelajaran IPA yang dilakukan dengan guru kelas IV diantaranya yaitu belajar siswa dalam memahami konsep dari pelajaran IPA tergolong masih rendah karena banyak guru menjumpai materi yang belum dapat dimengerti oleh siswa dengan benar. Hal itu disebabkan masih ada siswa yang setelah mengikuti proses pembelajaran belum bisa menjelaskan ulang materi yang sudah ia pelajari dan siswa tidak dapat menyebutkan contoh lain yang ada di dalam kehidupan sehari-hari (Hartini, 2019). Ada beberapa siswa yang belum bisa mengklasifikasi materi dan menyimpulkannya dengan menggunakan kalimatnya sendiri karena pelaksanaan proses belajar masih monoton pada guru yang dapat menjadikan siswa kurang adanya komunikasi dan motivasi sehingga siswa tidak mempunyai keberanian untuk mengungkapkan pendapat ketika pembelajaran berlangsung (Sudarsana et al., 2019). Pelajaran IPA bahkan dianggap siswa tidak menyenangkan sebab dalam pelaksanaanya selama pembelajaran berlangsung guru tidak menggunakan metode dan model akibatnya proses belajar sangat kurang bervariatif (Ariyanto, 2018; Darwis,dkk.,2016; Deliany,dkk.,2019; E., Putra, \& Suadnyana, 2016; Hartini, 2019; Hastuti \& Budianti, 2014; Safitri, Yennita, \& Idrus, 2018; Windasari, Suci \& Sofyan, 2018). 
Dari beberapa masalah yang muncul di sekolah SD tersebut menyebabkan hasil nilai belajar siswa menjadi rendah dan sangat kurang maksimal. Untuk mengatasi masalah yang seperti itu di sini guru harus melakukan beberapa tindakan yang bisa dilakukan misalkan menerapkan metode yang sesuai dengan materi dan lebih menarik lagi dan mengulang kembali materi yang di sampaikan agar siswa dapat memahami konsep tersebut (Deliany et al., 2019; Hastuti \& Budianti, 2014). Oleh sebab itu, dengan perkembangan ilmu teknologi dan pengetahuan yang memberikan kemudahan dalam penyampaian suatu hal di dunia pendidikan .

Salah satu hal yang bisa menarik perhatian siswa dalam belajar adalah menggunakan media ICT ( Informations and Communication Technologies) yang bisa memberikan suasana dalam penyampaian dan pemahaman suatu materi dengan mudah, bersemangat dan menyenangkan (Salim Nahdi,dkk., 2018; Sudarsana,dkk., 2019; Susanto, 2017). Di samping itu, guru perlu mengikuti perkembangan IPTEK yang selalu berubah-ubah agar para guru mampu meningkatkan mutu pendidikan dan agar pembelajaran dapat efektif dan tujuan bisa tercapai (Deliany,dkk., 2019; Febiharsa \& Djuniadi, 2018; Hayati \& Harianto, 2017; Safitri,dkk., 2018; Sudarsana,dkk., 2019). Dengan ini peneliti mencoba menggunakan model pembelajaran baru agar bisa meningkatkan pemahaman konsep siswa.

Dengan penggunaan media ICT ( Informations and Communication Technologies) dalam model Problem Based Learning ini peneliti punya harapan agar siswa bisa mengenal peristiwa yang ada di kehidupan nyata dan bisa mengubah gaya belajar yang bervariasi. Suatu pembelajaran yang menggunakan pendekatan yang berfokus pada suatu kelompok kecil dalam bekerja sama siswa harus bisa mengendalikan situasi agar siswa bisa belajar dengan baik dan dapat mencapai tujuan belajar dengan maksimal disebut pembelajaran kooperatif. Pembelajaran kooperatif memiliki keunggulan yaitu setiap anggota bisa saling membantu untuk menyelesaikan materi yang di terimanya. Probem Based Learning (PBL) yaitu gaya belajar yang mengikutsertakan seorang siswa dalam menyelesaikan masalah tertentu lewat beberapa tahapan dan metode, sehingga siswa dapat belajar tentang pengetahuanya sendiri yang ada kaitanya dengan masalah tersebut (L.E., 2018). PBL ini termasuk pembelajaran yang berbasis dengan suatu masalah dan dapat memberikan masalah yang ada kaitanya dengan kehidupan yang nyata, jadi PBL ini dapat mengajarkan kepada siswa untuk bisa bisa memperoleh pengetahuan dan berpikir kritis yang dapat memecahkan masalahnya tersebut dari mata pelajaran yag di pelajarinya.

Ada beberapa karakteristik yang dimiliki model PBL diantaranya : (1) mulai belajar dari suatu masalah, (2) masalah yang di berikan yang ada keterkaitanya dengan kehidupan sehari-hari siswa, (3) mengorganisasikan pelajaran dengan suatu masalah, (4) siswa harus bisa membentuk gaya belajar sendiri, (5) dapat membuat kelompok diskusi kecil, (6) siswa harus bisa menyampaikan pekerjaannya (Darwis,dkk., 2016; L.E., 2018; Muslim, Halim, \& Safitri, 2015; Safitri,dkk., 2018).

Berdasarkan uraian tersebut bisa ditarik kesimpulan bahwa pembelajaran PBL itu akan lebih menarik perhatian siswa dalam proses belajar dan bisa mengajarkan kepada siswa dengan sesuatu yang nyata atau konkret dalam kehidupan sehari-harinya, karena di sini siswa bisa belajar memecahkan suatu

323 BRILIANT: Jurnal Riset dan Konseptual Volume 6 Nomor 2, Mei 2021 
masalah yang membuatnya berpikir kritis dan menjadi tahu pengalaman mereka dalam mengetahui pengetahuan yang ia pelajari. Jadi siswa dalam hal ini bisa dikatakan pada belajar suatu konsep yang penyelesaian masalahnya melalui tahap pengetahuannya sendiri. Sehingga siswa dapat mengintegrasikan pengetahuannya dengan keterampilam secara berkesinambungan dan bisa mengimplementasikan dalam kehidupan sehari-hari.

PBL memiliki kelebihan antara lain siswa bisa lebih bebas dalam berinteraksi dan mengelurarkan gagasan idenya, mempunyai sifat percaya diri yang tinggi, motivasi belajar siswa jadi meningkat, pemahaman akan tumbuh mendalam terhadap pokok bahasan, menumbuhkan sikap toleransi terhadap pesert didik yang lainya, kerja sama antar peserta didik dengan yang lainnya dapat tercipta interaksi yang baik, membuat siswa dapat berpikir kritis dalam memcahkan masalah, siswa dapat mengenal suatu yang real atau konkret berdasarkan pengalaman. Namun, PBL juga memiliki kekurangan, antara lain kadang terjadi perbedaan pendapat, terlalu banyak memakan waktu yang cukup lama, jika guru tidak bisa menciptakan suasana kelas yang tenang maka bisa terjadi kegaduhan. PBL juga mengajarkan siswa untuk berpikir kritis, menumbuhkan rasa inisiatif siswa dalam bekerja di suatu kelompok kecil maupun besar, dapat memberikan semangat belajar dengan memberikan motivasi dan menjalin hubungan dengan teman satu ke teman lainya untuk bekerja dalam kelompok serta kecepatan dan ketepatan dalam bekerja di suatu tim kecil.

Berdasarkan latar belakang yang sudah dijelaskan, peneliti ingin meningkatkan kembali proses pembelajaran siswa dengan meningkatkan pemahaman konsep siswa yang di harapkan dengan tujuan pembelajaran bisa tercapai dengan baik maka peneliti menggunakan judul "Penggunaan Media ICT (Informations and Communication Technologies) Dalam Implementasi Model Pembelajaran Problem Basedd Learning Terhadap Hasil Belajar Siswa Untuk Meniingkatkan Pemahaman Konsep Pada mapel IPA Materi Siklus Hidup Beberapa Jenis Hewan Pada Kelas 4 SD”.

\section{METODE}

Jenis metode ini menggunakan metode quasi experiment kuantitatif desain pretest and postest (Cresswel, 2013). Metode ini selaras dengan penelitian Kartikasari (2016) peneliti menggunakan dua kelas yaitu kelas eksperimen dan kontrol. Pada kelasz eksperimen diberi perllakuan dengan model PBL sedangkan kelas control cukup di ajarkan dengan metode konvensional. Pada masing-masing kelas diawali dengan pretest dan setelah itu diadakan pemberian perlakuan untukk pengukuran ulang dengan posttest

Tabel 1. Desain penelitian Eksperiment

\begin{tabular}{|l|l|l|l|}
\hline Kelompok & Pretest & $\begin{array}{l}\text { Variabel } \\
\text { bebas }\end{array}$ & Posttest \\
\hline $\mathrm{E}$ & $\mathrm{O}_{1}$ & $\mathrm{X}$ & $\mathrm{O}_{2}$ \\
\hline $\mathrm{K}$ & $\mathrm{O}_{1}$ & & $\mathrm{O}_{2}$ \\
\hline
\end{tabular}

Keterangan:

E : kelas eksperimen

324 BRILIANT: Jurnal Riset dan Konseptual

Volume 6 Nomor 2, Mei 2021 
K : kelas kontrol

$\mathrm{O}_{1} \quad$ : Pretest diberikan pada kelompok eksperimen dan kontrol yang tidak diberi perlakuan

$\mathrm{O}_{2}$ :posttest dibagikan pada kelompok eksperimen dan kontrol setelah mendapat perlakuan

$\mathrm{X} \quad$ : Penggunaan pembelajaran PBL pada kelas eksperimen.

Pengumpulan data yang di pilih adalah tes. Ada dua kali proses yamg dilakukan yaitu pretest dan posttest. Tes tersebut berupa soal pilihan ganda yang sudah di susun berdasarkan indikator. Teknik yang digunakan dalam pengumpulan data ialah tes dan dokumentasi. Untuk mengetahui hasil akhir terhadap pemahaman konsep IPA yang di lakukan selama proses pembelajaran dapat dilakukan dengan metode tes. Instrument yang digunakan adalah lembar tes. Dan lmbar tes terdiri dari pretest dan postest. Test ini berupa pilihan ganda yang berjumlah 10 untuk pretest dan 10 untuk postest. Bobot soal dalam tes ini adalah 10. Lembar pretest diberikan sebelum pembelajaran menggunakan model PBL sedangkan lembar postest di berikan setelah pembelajaran menggunakan model PBL. Teknik analisa data tes pemahaman konsep dilakukan agar dapat memperoleh selisih dari skor maksimal dengan tes awal. Dan hasilnya yang sudah dilakukan sebelum dan sesudah pembelajaran dihitung dengan :

$$
\text { Indeks-Gain }=\frac{S_{\text {post }}-S_{\text {pre }}}{S_{\max }-S_{\text {pre }}} \times 100
$$

Jika ingin melihat perkembangan siswa selama sebelum dan setelah proses pembelajaran dengan mengaplikasikan model PBL berbasis media ICT dapat dilihat dari Nilai Gain tersebut.

Kategori nilai N-Gain :

$\geq 75=$ berhasil atau tuntas

$\leq 75$ = gagal atau tidak tuntas

\section{HASIL DAN PEMBAHASAN}

Peneliti menggunakan tes sebelum dan sesudah belajar agar dapat mengetahui perubahan hasill belajar siswa tersebut. Pretest yang dilakukan dikelas eksperiimen sebelum siswa mendapattkan perlakuan dan posttest dilakukan setelah siswa sudah mendapattkan perlakuan. Sedangkan kelas control pretest diberikan sebelum model pembelajaran konvensional dilakukan. Dari kelas eksperimen dan kontrol terdapat hasil tes dan kemudian dari hasil tersebut di analisisa secara keseluruhan, dari hasill penyelidikan data tersebut dapat dilihat selama pembelajaran siswa sesudah dan sebelum akan terjadi peningkatan belajar. Untuk mengetahui keberhasilan peningkatan siswa belajar dapat dilihat dari nilai KKM (Kriteria Ketuntasan Minimum). Siswa dikatakan berhasil jika nilai $\geq 75$ dan apabila siswa dikatakan gagal maka nilai yang diperoleh $\leq 75$.

Tabel 2. Nilai pretest siswa

\begin{tabular}{|l|l|l|}
\hline Jumlah siswa & Tidak tuntas $\leq 75$ & Tuntas $\geq 75$ \\
\hline 17 laki laki & 10 anak & 7 anak \\
\hline
\end{tabular}

325 BRILIANT: Jurnal Riset dan Konseptual

Volume 6 Nomor 2, Mei 2021 


\begin{tabular}{|l|l|l|}
\hline 18 perempuan & 13 anak & 5 anak \\
\hline Rata-rata nilai & $\leq 65$ & $\geq 75$ \\
\hline
\end{tabular}

Dari data tersebut dapat dilihat bahwa terdapat siswa yang pemahaman konsepnya masih terbilang rendah dan belum mencapai nilai KKM yang sebagaimana yang sudah ditentukan guru sebelumnya. Untuk meningkatkan belajar siswa supaya guru bisa tau sampai mana pemahaman siswa selama di kelas guru harus melakukan suatu pembelajaran terlebih dahulu sebelum dilakukan tes selanjutnya

Tabel 3. Nilai posttest siswa

\begin{tabular}{|l|l|l|}
\hline Jumlah siswa & Tidak tuntas $\leq 75$ & Tuntas $\geq 75$ \\
\hline 17 laki laki & 2 anak & 15 anak \\
\hline 18 perempuan & 3 anak & 15 anak \\
\hline Rata-rata nilai & $\leq 65$ & $\geq 80$ \\
\hline
\end{tabular}

Dari nilai tes keseluruhan dapat dilihat jika ada peningkatan siswa yang dapat dilihat dikelas eksperimen dengan menerapkan model PBL, dibandingakan kelas kontrol yang hanya mendapatkan pembelajaran secara konvensional. Dalam uraian tersebut dapat diartikan bahwa dikelas eksperimen pemahaman siswanya lebih bagus di bandingkan di kelas kontrol yang hanya mendapatkan pembelajaran secara monoton. Selisih perolehan nilai dapat dilihat dari rata-rata tes akhir dari dua kelas tersebut, karena dalam pembelajaran di kelas eskperimen siswa mendapat banyak kesempatan untuk bisa belajar memecahkan masalah baik secara individu maupun bersama. PBL ini juga bisa mengajarkan siswa cara bekerja sama untuk mencari solusi dari masalah yang dihadapinya.

\section{KESIMPULAN}

Berdasarkan masalah yang muncul dari pembahasan analisa data, hasil yang sudah dipaparkan sebelumnya bisa disimpulkan bahwa dengan menggunakan model PBL terjadi pengaruh terhadap meningkatnya pemahaman konsep terhadap pembelajaran siswa. Meningkatnya pemahaman siswa terjadi pada kelas eks dan bukan pada kelas kontrol. Oleh sebab itu guru dituntut bisa mengembangkan pembelajaran di kelas dengan menggunakan ide yang kreatif dan inovatif agar tujuan pembelajaran bisa tercapai dengan baik.

\section{SARAN}

Penggunaan model PBL hendaknya bisa dijadikan alternatif guru di sekolah untuk meningkatkan hasil bealajar khususnya mata pelajaran IPA. Guru harus menciptakan suasana kelas menjadi menyenangkan dan nyaman agar siswa bisa belajar dengan baik dan guru juga harus tepat dalam memilih model, metode, media yang ingin diajarkan untuk siswanya agar pelaksanaan belajar secara langsung bisa berjalan dengan baik. Untuk siswa alangkah lebih baiknya bisa berperan aktif dalam kelas selama kegiatan belajar langsung agar bisa mencapai hasil belajar yang maksimal sesuai dengan kemampuanya. Dan untuk sekolah di harapkan agar bisa menyediakan sarana yang ada di sekolah terutama di ruangan supaya kegiatan belajar mengajar dapat berjalan dengan baik. 


\section{DAFTAR RUJUKAN}

Ariyanto, M. (2018). Peningkatan Hasil Belajar Ipa Materi Kenampakan Rupa Bumi Menggunakan Model Scramble. Profesi Pendidikan Dasar. https://doi.org/10.23917/ppd.v3i2.3844

Cresswel, J. (2013). Qualitative, quantitative, and mixed methods approaches. In Research design. https://doi.org/10.2307/3152153

Darwis, M., Pendidikan, D., Fakultas, B., Dan, K., Pendidikan, I., Muhammadiyah, U., \& Selatan, T. (2016). Upaya Meningkatkan Kreativitas Belajar Ilmu Pengetahuan Aalam (IPA) Melalui Penerapan Model Pembelajaran Problem Based Learning Di MTs Muhammadiyah 7 HASAHATAN JULU. JURNAL EKSAKTA.

Deliany, N., Hidayat, A., \& Nurhayati, Y. (2019). Penerapan Multimedia Interaktif untuk Meningkatkan Pemahaman Konsep IPA Peserta Didik di Sekolah Dasar. Educare. https://doi.org/10.36555/educare.v17i2.247

Febiharsa, D., \& Djuniadi, D. (2018). Pengembangan Media Pembelajaran Interaktif 3 Dimensi untuk Pembelajaran Materi Pengenalan Lingkungan Pada Anak Usia Dini di Indonesia. Journal of Studies in Early Childhood Education (J-SECE). https://doi.org/10.31331/sece.v1i1.590

Hartini, H. (2019). Peningkatan Kemandirian dan Prestasi Belajar IPA melalui Problem Based Learning berbantuan Lembar Kerja Siswa. Paedagogie. https://doi.org/10.31603/paedagogie.v14i1.2678

Hastuti, A., \& Budianti, Y. (2014). Pengaruh Penggunaan Media Audio Visual Terhadap Hasil Belajar Siswa Pada Mata Pelajaran Ipa Kelas II Sdn Bantargebang Ii Kota Bekasi. Pedagogik.

Hayati, N., \& Harianto, F. (2017). Hubungan Penggunaan Media Pembelajaran Audio Visual dengan Minat Peserta Didik pada Pembelajaran Pendidikan Agama Islam di SMAN 1 Bangkinang Kota. Al-Hikmah: Jurnal Agama Dan Ilmu Pengetahuan. https://doi.org/10.25299/alhikmah:jaip.2017.vol14(2).1027

Kartikasari, Erlin. (2016). Pengaruh Penggunaan Model Pembelajaran Raja Darmawan Terhadap Keterampilan Berbicara Bahasa Indonesia Untuk Penutup Asing (BIPA) Di Surabaya European School Indonesia. Prosiding Seminar Nasional.28 Mei 2016. ISBN 24600318.

L.E., E. P. (2018). Cooperative Learning Dengan Model TGT (Teams Games Tournament) Materi Bilangan Bulat Bagi Siswa Kelas IV Sekolah Dasar Buana Matematika : Jurnal Ilmiah Matematika Dan Pendidikan Matematika. https://doi.org/10.36456/buana_matematika.7.2:.1048.85-88

Muslim, I., Halim, A., \& Safitri, R. (2015). Penerapan Model Pembelajaran PBL Untuk Meningkatkan Penguasaan Konsep dan Keterampilan Berpikir Kritis Siswa Pada Konsep Elastisitas Dan Hukum Hooke di SMA Negeri Unggul Harapan Persada. Jurnal Pendidikan Sains Indonesia (Indonesian Journal of Science Education).

Safitri, M., Yennita, Y., \& Idrus, I. (2018). Upaya Meningkatkan aktivitas dan Hasil Belajar IPA Siswa Melalui Penerapan Model Problem Based Learning (PBL). Diklabio: Jurnal Pendidikan Dan Pembelajaran Biologi. https://doi.org/10.33369/diklabio.2.1.103-112

Salim Nahdi, D., Yonanda, D. A., \& Agustin, N. F. (2018). Upaya Meningkatkan Pemahaman Konsep Siswa Melalui Penerapan Metode Demonstrasi Pada 
Mata Pelajaran IPA. Jurnal Cakrawala Pendas. https://doi.org/10.31949/jcp.v4i2.1050

Sudarsana, I. K., Nakayanti, A. R., Sapta, A., Haimah, Satria, E., Saddhono, K., ... Mursalin, M. (2019). Technology Application in Education and Learning Process. Journal of Physics: Conference Series. https://doi.org/10.1088/1742-6596/1363/1/012061

Surahman, Paudi, R. I., \& Tureni, D. (2015). Meningkatkan Hasil Belajar Siswa Dalam Pembelajaran IPA Pokok Bahasan Makhluk Hidup Dan Proses Kehidupan Melalui Media Gambar Kontekstual Pada Siswa Kelas II SD Alkhairaat Towera. Jurnal Kreatif Tadulako Online.

Susanto, A. (2017). Pemanfaatan ICT (Informations and Communication Technologies) dalam Pembelajaran Anak Usia Dini. Tarbawy: Jurnal Pendidikan Islam. https://doi.org/10.32923/tarbawy.v4i2.820 